\title{
Neurodegenerative Disorders and Prionopathies
}

\section{Jin Jun Luo ${ }^{1,2}$ and Nae J Dun²}

${ }^{1}$ Departments of Neurology, Temple University School of Medicine, Philadelphia, USA

${ }^{2}$ Departments of Pharmacology, Temple University School of Medicine, Philadelphia, USA

Neurodegenerative disorders are a group of progressively worsening neurological disorders caused by neuronal degeneration in the brain. Depending on the location, degeneration in the cerebral cortex causes dementia including Alzheimer's disease (AD), Pick's disease (PiD), and diffuse Lewy Body dementia (DLBD). In the basal ganglia, brainstem and cerebellum, degeneration causes Parkinson's disease (PD), Huntington's disease (HD), multisystem atrophy (MSA), dentatorubropallidoluysian atrophy, Freidreich's ataxia, multiple system atrophy, and types 1, 2, 3, 6, 7 spinocerebellar ataxia. Degeneration that involves only motor neurons causes amyotrophic lateral sclerosis (ALS), familial spastic paraparesis, spinal muscular atrophy, spinal and bulbar muscular atrophy.

Prion diseases, also called TSE (transmissible spongiform encephalopathies), are a rare group of fatal neurodegenerative disorders affecting humans and animals. In humans, prion diseases include Creutzfeldt - Jakob disease (CJD), Variant Creutzfeldt-Jakob disease (vCJD), Gerstmann-Straussler-Scheinker syndrome, fatal familial insomnia and Kuru disease. Prion diseases can be sporadic, inherited or familial, iatrogenic, and variant forms. The most common prion disease is sporadic CJD, which is characterized by dementia, ataxia and myoclonus, and, pathologically, amyloid deposits composed of mainly prion proteins [1]

Since established two decades ago, the concept of prion disease has significantly impacted both the basic neuropathological research and clinical neurology practice. Prions, as a group of infectious selfreproducing pathogens, comprise a protein that resists inactivation by procedures that modify nucleic acid [2]. Dr. Stanley B. Prusiner discovered prions in 1982 at the University of California, San Francisco and his work lead to the 1997 Nobel Prize in physiology.

Prions are produced by recruiting the normal cellular isoform of the prion protein $\mathrm{PrP}^{\mathrm{c}}$ and stimulating its conversion into the diseasecausing isoform $\mathrm{PrP}^{\mathrm{sc}}$. The normal isoform $\mathrm{PrP}^{\mathrm{c}}$ is a glycoprotein containing 208 amino acids derived from a precursor $\operatorname{PrP}$ of 253 amino acids. $\mathrm{PrP}^{c}$ comprises approximate $45 \%$ a-helical with only two very short stretches of $\beta$-sheet, while $\operatorname{PrP}^{\mathrm{sc}}$ has less than $30 \% \alpha$-helix and approximate $45 \% \beta$-sheet [3]. $\operatorname{PrP}^{c}$ is tethered to the cell surface via a glycosyl phosphatidyl inositol (GPI) anchor at the protein's C terminus [4]. Under physiological conditions, $\operatorname{PrP}^{c}$ folds into its characteristic and functional three-dimensional structure, despite the fact that its physiologic roles remain unknown. The misfolded $\operatorname{PrP}^{s c}$ is the main pathological component of the $\beta$-sheet febrils in prion diseases. There are two models to explain the conformational conversion of $\mathrm{PrP}^{\mathrm{c}}$ into $\mathrm{PrP}^{\mathrm{sc}}$ : the "template-directed refolding" and the "seeded nucleation" hypotheses. The former hypothesis predicates a role for $\mathrm{PrP}^{\mathrm{sc}}$ on $\mathrm{PrP}^{\mathrm{c}}$. A single $\operatorname{PrP}^{\mathrm{sc}}$ molecule binds to a single $\operatorname{PrP}^{\mathrm{c}}$ molecule and catalyzes its conversion into $\operatorname{PrP}^{\mathrm{sc}}$. The two $\mathrm{PrP}^{\mathrm{sc}}$ molecules then come apart and can go on to convert more $\mathrm{PrP}^{\mathrm{c}}$ [5]. In the "seeded nucleation" hypothesis, the infectious agent would consist of a highly ordered aggregate of $\mathrm{PrP}^{\mathrm{sc}}$ molecules. The aggregated state is the fundamental property of infectivity [6-8].

Prion diseases are transmissible because inoculation or transplantation of the diseased brain or non-brain tissue in humans and animals has reproduced prion diseases $[9,10]$. Notably, CJD has also been observed in recipients of human organ transplantations and in cannibals $[9,10]$, though it may require a long incubation time to develop the disease. For example, a particular pattern at 10-19 years' incubation latency was observed in surgical transmission of CJD [11]. Transmission of prions from animals to humans, such as mad cow disease, is believed to have caused more than 200 cases of vCJD [12]. Pathologically, prion diseases cause spongiosis, neuronal loss, astrogliosis, and accumulation of misfolded $\mathrm{PrP}^{\mathrm{sc}}$. Prion diseases are characterized by widespread neurodegeneration.

Robust evidence from basic and clinical studies has revealed that many similarities are shared in neurodegenerative disorders, including prion diseases, at many different levels ranging from molecular to systemic. Clinical observations in general showed that the majority of those diseases are sporadic, while only approximately $10 \%$ familial forms [13]. The onset of symptoms is commonly in late adult life instead of youth even in the inherited forms. The pathologic findings showed abnormal accumulations of extracellular or intracellular fibrils and/or inclusions suggestive of the presence of a misassembling or misfolding protein. Misassembled or misfolded proteins aggregate and form fibrils and/or inclusions are seen in the brains of patients with $\mathrm{AD}, \mathrm{DLBD}, \mathrm{PD}, \mathrm{PiD}, \mathrm{MSA}$, and ALS, and $\mathrm{PrPsc}$ in CJD. Laboratory findings disclosed that abnormal aggregations may interfere with neuronal functions including axonal transport, membrane integrity, intracellular signal transduction, mitochondrial function, and eventually cause programmed cell death $[8,9,14-16]$.

Recent studies showed that the pathology of AD, PD and ALS can be transmitted to animals in a way similar to that by which a prion disease was transmitted with $\operatorname{PrP}$ inoculation. For example, amyloid(A $\beta)$ peptide induced aggregation occurred in transgenic mice or primates after injection of AD brain extracts or purified and synthetic $A \beta$ peptides [17-19]. Intraperitoneal injection of mouse brain extracts containing $A \beta$ aggregates or tau protein resulted in amyloid deposition and other pathological alterations in the recipient mice $[9,20]$. Injection of synthetic oligomeric mouse $\alpha$-synuclein, a pathologic protein in $\mathrm{PD}$, into the substantia nigra of wild-type mice, induced spreading of $a$-synuclein throughout the brain and recapitulated the Parkinsonian phenotype, losing dopaminergic nigral neurons, reducing striatal dopamine levels and resulting in motor deficits [21]. Inclusion formation and neuronal cell death through neuron-to-neuron transmission of

*Corresponding author: Dr. J.J. Luo, Departments of Neurology and Pharmacology, Temple University School of Medicine, 3401 North Broad Street, Suite C525, Philadelphia, PA 19140, USA, Tel: 1-215-707-3040; Fax: 1-215-7078235; E-mail: jluo@temple.edu

Received May 27, 2013; Accepted June 01, 2013; Published June 05, 2013

Citation: Luo JJ, Dun NJ (2013) Neurodegenerative Disorders and Prionopathies. J Neurol Neurophysiol 4: e113. doi:10.4172/2155-9562.1000e113

Copyright: (c) 2013 Luo JJ, et al. This is an open-access article distributed under the terms of the Creative Commons Attribution License, which permits unrestricted use, distribution, and reproduction in any medium, provided the original author and source are credited. 
a-synuclein was demonstrated in vitro and in vivo models for PD $[22,23]$. Changes in levels of enkephalin in the amygdala and globus pallidus were observed in the injected mice, reflecting neuronal dysfunction resulting from aggregate pathology [24]. Interestingly, a-synuclein inclusions found in the submucosal Meissner plexus of the enteric nervous system [25] can be transmitted to the CNS via vagus nerves [26], and subsequently, activate intracellular $\alpha$-synucleinassociated Lewy body pathology in PD [27]. Importantly, neurological disorders can be produced by either peripheral (extracerebral) or direct brain (intracerebral) inoculation [22,23]. Those findings provide evidence of cell-to-cell spread of pathologic proteins of neurological disorders in animals, suggesting those pathological proteins may have seeding abilities, like prion diseases, to transmit pathology $[17,28]$.

To date, there is no direct evidence in humans indicating that the diseases caused by misfolded $A \beta$, tau, $\alpha$-synuclein are infectious. However, the possibility that the neurodegenerative disorders might be transmitted from person to person may not be balderdash. For example, a prion may be taken up by dendritic cells through the skin $[9,29]$. In prion diseases, $\mathrm{PrP}^{\mathrm{sc}}$ and its infectivity levels do not always correlate well. The presence of little or no $\mathrm{PrP}^{\mathrm{sc}}$ in brain tissue may still have high levels of infectivity [30,31] and peripheral tissue may have, sometimes even higher, infectivity [32]. Clinically, a familial form of prion disease can manifest a neurological disorder, such as $\mathrm{AD}$, with the presentations of typical pathology and clinical phenotype [33].

The discovery of a possible prion-like infection mechanism in neurological diseases such as $\mathrm{AD}$ and $\mathrm{PD}$ would significantly influence the direction of research on the pathogenesis of these neurodegenerative disorders, and would be a significant step towards developing effective therapeutic approaches, as the current treatments have been disappointing. If proven to be correct, the concept of prionopathies for neurodegenerative disorders may significantly impact clinical practice.

\section{References}

1. Biljan I, Giachin G, Ilc G, Zhukov I, Plavec J, et al. (2012) Structural basis for the protective effect of the human prion protein carrying the dominant-negative E219K polymorphism. Biochem J 446: 243-251.

2. Prusiner SB (1982) Novel proteinaceous infectious particles cause scrapie. Science 216: 136-144.

3. Riek R, Hornemann S, Wider G, Billeter M, Glockshuber R, et al. (1996) NMR structure of the mouse prion protein domain $\operatorname{PrP}(121-231)$. Nature 382: 180182

4. Jones CE, Abdelraheim SR, Brown DR, Viles JH (2004) Preferential Cu2+ coordination by His 96 and His 111 induces beta-sheet formation in the unstructured amyloidogenic region of the prion protein. J Biol Chem 279: 32018-32027.

5. Cohen FE, Pan KM, Huang Z, Baldwin M, Fletterick RJ, et al. (1994) Structural clues to prion replication. Science 264: 530-531.

6. Aguzzi A, Polymenidou M (2004) Mammalian prion biology: one century of evolving concepts. Cell 116: 313-327.

7. Jarrett JT, Lansbury PT Jr (1993) Seeding "one-dimensional crystallization" of amyloid: a pathogenic mechanism in Alzheimer's disease and scrapie? Cell 73: 1055-1058.

8. Hu PP, Huang CZ (2013) Prion protein: structural features and related toxicity. Acta Biochim Biophys Sin (Shanghai) 45: 435-441.

9. Aguzzi A, Calella AM (2009) Prions: protein aggregation and infectious diseases. Physiol Rev 89: 1105-1152.

10. Will RG (2003) Acquired prion disease: iatrogenic CJD, variant CJD, kuru. Br Med Bull 66: 255-265.

11. de Pedro-Cuesta J, Mahillo-Fernández I, Rábano A, Calero M, Cruz M, et al. (2011) Nosocomial transmission of sporadic Creutzfeldt-Jakob disease: results from a risk-based assessment of surgical interventions. J Neurol Neurosurg Psychiatry 82: 204-212.

12. CDC vCJD (Variant Creutzfeldt-Jakob Disease) (2013) Centers for Disease Control and Prevention. http://www.cdc.gov/ncidod/dvrd/vcjd/factsheet_nvcjd. htm\#reported.

13. Prusiner SB (2012) Cell biology. A unifying role for prions in neurodegenerative diseases. Science 336: 1511-1513.

14. Dueñas AM, Goold R, Giunti P (2006) Molecular pathogenesis of spinocerebellar ataxias. Brain 129: 1357-1370.

15. Breydo L, Wu JW, Uversky VN (2012) A-synuclein misfolding and Parkinson's disease. Biochim Biophys Acta 1822: 261-285.

16. Dikiy I, Eliezer D (2012) Folding and misfolding of alpha-synuclein on membranes. Biochim Biophys Acta 1818: 1013-1018.

17. Meyer-Luehmann M, Coomaraswamy J, Bolmont T, Kaeser S, Schaefer C, et al. (2006) Exogenous induction of cerebral beta-amyloidogenesis is governed by agent and host. Science 313: 1781-1784

18. Ridley RM, Baker HF, Windle CP, Cummings RM (2006) Very long term studies of the seeding of beta-amyloidosis in primates. J Neural Transm 113: 12431251.

19. Stöhr J, Watts JC, Mensinger ZL, Oehler A, Grillo SK, et al. (2012) Purified and synthetic Alzheimer's amyloid beta $\left(A \hat{I}^{2}\right)$ prions. Proc Natl Acad Sci U S A 109: 11025-11030.

20. Eisele YS, Obermüller U, Heilbronner G, Baumann F, Kaeser SA, et al (2010) Peripherally applied Abeta-containing inoculates induce cerebral betaamyloidosis. Science 330: 980-982.

21. Luk KC, Kehm V, Carroll J, Zhang B, O'Brien P, et al. (2012) Pathological a-synuclein transmission initiates Parkinson-like neurodegeneration in nontransgenic mice. Science 338: 949-953.

22. Desplats P, Lee HJ, Bae EJ, Patrick C, Rockenstein E, et al. (2009) Inclusion formation and neuronal cell death through neuron-to-neuron transmission of alpha-synuclein. Proc Natl Acad Sci U S A 106: 13010-13015.

23. Olanow CW, Brundin P (2013) Parkinson's disease and alpha synuclein: is Parkinson's disease a prion-like disorder? Mov Disord 28: 31-40.

24. Masuda-Suzukake M, Nonaka T, Hosokawa M, Oikawa T, Arai T, et al. (2013) Prion-like spreading of pathological Ît-synuclein in brain. Brain 136: 1128-1138.

25. Braak H, de Vos RA, Bohl J, Del Tredici K (2006) Gastric alpha-synuclein immunoreactive inclusions in Meissner's and Auerbach's plexuses in cases staged for Parkinson's disease-related brain pathology. Neurosci Lett 396: 6772.

26. Hawkes CH, Del Tredici K, Braak H (2009) Parkinson's disease: the dual hit theory revisited. Ann N Y Acad Sci 1170: 615-622.

27. Luk KC, Song C, O'Brien P, Stieber A, Branch JR, et al. (2009) Exogenous alpha-synuclein fibrils seed the formation of Lewy body-like intracellular inclusions in cultured cells. Proc Natl Acad Sci U S A 106: 20051-20056.

28. Kim J, Holtzman DM (2010) Medicine. Prion-like behavior of amyloid-beta Science 330: 918-919.

29. Taylor DM, McConnell I, Fraser H (1996) Scrapie infection can be established readily through skin scarification in immunocompetent but not immunodeficient mice. J Gen Virol 77 : 1595-1599.

30. Barron RM, Campbell SL, King D, Bellon A, Chapman KE, et al. (2007) High titers of transmissible spongiform encephalopathy infectivity associated with extremely low levels of PrPSc in vivo. J Biol Chem 282: 35878-35886.

31. Lasmézas Cl, Deslys JP, Robain O, Jaegly A, Beringue V, et al. (1997) Transmission of the BSE agent to mice in the absence of detectable abnormal prion protein. Science 275: 402-405.

32. K. Dobie, and R. Barron (2013) Dissociation between Transmissible Spongiform Encephalopathy (TSE) Infectivity and Proteinase K-Resistant PrPSc Levels in Peripheral Tissue from a Murine Transgenic Model of TSE Disease. J Virol 87- 5895-5903.

33. Jayadev S, Nochlin D, Poorkaj P, Steinbart EJ, Mastrianni JA, et al. (2011) Familial prion disease with Alzheimer disease-like tau pathology and clinical phenotype. Ann Neurol 69: 712-720. 